\title{
Fuelwood Scarcity, Poverty and Women: Some perspectives
}

\author{
Varinder Singh Waris ${ }^{1}$ and Dr. Prakash C. Antahal ${ }^{2}$ \\ ${ }^{I}$ (Research Scholar,Department of Economics' University of Jammu,J\&K, India) \\ 2 (Professor in Department of Economics, University of Jammu, J\&K, India)
}

\begin{abstract}
Wood has been used since prehistorical times for cooking and heating and remains the primary energy source for billions of people throughout the world. It is an alarming fact that today in the 21st century there are still billions of people who totally depend on wood for cooking food. Currently about 2.7 billion people in developing countries who rely for cooking primarily on wood and out of 2.7 billion people $82 \%$ live in rural areas. No doubt, other alternatives to the fuelwood are also available in some parts of the developing countries but people mostly prefer fuelwood as their major cooking fuel due to perhaps rising liquid fuel cost ( LPGs and Kerosene ), poverty, unemployment, and population pressure etc. with that, the demand for fuelwood is increasing continuously, while with the passage of time supply of fuelwood is declining, with the expansion of cultivated area, land under forests shrunk as a result of diversion of forests land to agriculture. This continuously widening gap between demand for and supply of fuelwood resulted in fuelwood scarcity problem.

This paper shows the impact of fuelwood scarcity on women as it exists today, in order to plan for future. Fuelwood scarcity has vitally affected lives of millions of women economically, socially and physically especially in developing nations, who shoulder a major part of responsibility for the survival of the household. With the scarcity of fuelwood, women who are traditionally responsible to search, collect, load and carry fuelwood from the forests have to spend more hours for searching and collecting fuelwood and for such purpose they have to cover large distance which results into the wastage of precious time, hindering other important activities of women, limiting their opportunities to earning and obtain education etc. This process again put them into the grip of poverty, poverty again responsible for fuelwood scarcity which again led to the deterioration of women economically, socially and physically. Besides, this paper also shows the correlation between poverty and deficit availability of fuelwood, link between poverty, women and fuelwood scarcity and suggested some important solutions to cope with the problem of fuelwood scarcity.

In addition to this, paper shows reducing poverty as a pre-condition to cope with the problem of fuelwood scarcity which is associated with the problem of women.
\end{abstract}

Keywords: Fuelwood scarcity, land diversion, poverty, women deterioration.

\section{Introduction}

Fuelwood is the forest commodity produced in large quantities and is the principal component of rural domestic energy in India and in many other developing countries. It is an alarming fact that today in the $21^{\text {st }}$ century there are still billions of people who totally rely on wood for cooking food. According to the International Energy Agency (IEA) there are currently about 2.7 billion people in the developing countries who rely for cooking primarily on wood, tree leaves, etc. Used inefficient devices like 3-stone fire (inefficient cook stove), mud stoves, brick stoves with no operating chimney or hoods. Out of 2.7 billion people $82 \%$ live in rural areas. In India the number of people relying on the traditional use of biomass for cooking are 855 million in 2009 (765 million in rural areas and 90 million in urban areas). This number is higher than previously estimated in WEO(World Energy Outlook) in 2008 due to perhaps increase in population, rising liquid fuel cost and global economic recession, which may have driven a number of people back to using traditional biomass. As per the 2011 Census, almost $85 \%$ of rural households in India were dependent on traditional biomass fuels for their cooking energy requirements. Further, as per the NSSO Reports (55th, 61st and 66th Rounds), there has been an increase in biomass fuel use in terms of absolute quantity consumed over the past decade among rural households. This phenomenon is unlikely to change significantly even in the long term as many of these countries, though struggling to advance, are still the bottom of the development ladder. The share of population relying on traditional use of biomass is highest in Sub-Saharan Africa and India.

With the expansion of cultivated area, land under forests shrunk as a result of diversion of forest land to agriculture. On the other hand the demand for fuel wood is increasing continuously in spite of the fact that commercial energy sector in India has grown rapidly. The missing energy resources (fuel wood scarcity) impose time and labor burden on the rural households and has linkage with poverty, health and education of the people in these areas directly or indirectly. This situation is not expected to change in near future. 
The scarcity of fuelwood has increased the time burden especially of women, who are traditionally responsible for collecting fuelwood for domestic purposes in many parts of developing countries. With the increase in the scarcity of fuel wood, women and girls have to walk many miles to get a head load of fuel wood every day. As we know that collecting fuel wood is a time consuming and exhausting task.

Women time burden for the collection of fuel wood tends to increase in cases where men migrate to urban centers in research of employment. Also, women can suffer serious long-term physical damage from strenuous work without sufficient recuperation. This risk, as well as the hazard of falls from tree, insect bites, or human assault etc. rises steeply the further from home women have to walk.

Fuelwood scarcity places major demands on women and children's time, limiting their opportunities to obtain an education and undertake income generating activities. An increase in the fuelwood collection time may force girls to drop out of schools to asset their mothers in households and other chores, thus hindering their education.

Fuelwood scarcity adversely affected women's income generating activities like-sewing, handicrafts etc. and direct impact on women health-rates of maternal death, impact on their participation in important activities like family planning programmes, health and nutrition programmes, participation in creating new laws and public policies. They have concerns with the risk associated stealing fuelwood (e.g. breaking their legs while running, financial penalties etc.) from private forests since they did not have access to community forests. Fuelwood scarcity also affects their cooking habits; women do not boil water enough, cook food items with low nutritional value that require less cooking time. This in turn, affects family health.

Even though some substitutions are also available at some villages-dung cake, electricity, kerosene, in some cases LPGs etc. but people still preferred wood for preparing local dishes due to various economic, social and religious causes. But poverty and unemployment is the basic cause of why people mostly used fuelwood in developing countries especially in India.

Time burden of women may be reduced by providing modern fuels and stoves at highly subsidized rates to Below Poverty Line (BPL) families and at moderate rates to middle income families.

Where modern technologies are available for cooking i.e. LPG, biogas, improved stoves etc. men also share the cooking responsibilities such as preparing light snacks, carrying cylinders for family and thus saved time of women for income generating activities, participating welfare activities etc. but where these modern technologies are absent women and children are mostly responsible.

The non-availability of fuel wood within the villages is an indicator of the forests in these areas have been over exploited, given the fact that, in the past, this was not the situation and people would have enough forests within the village itself to fulfill their requirements.

The problem of fuel wood scarcity can be understood from the following fact: Around towns and villages circles of tree-less area were widening; a lot of wood is wasted in inefficient wood stoves. Improved stoves were therefore thought to have a great potential.

Interventions aimed at the regeneration of forests at the watershed level have not been very successful because of the approach being to protect the forests from the local rather than by the local communities which resulted into lack of local participation in the management and planning of common property resources (CPRs) and alienation of the local communities.

\section{Review Of Literature}

The studies in this subject reflect a wide diversity of disciplinary backgrounds and interests among the contributors. The studies themselves, however, have a number of foci in common. All too some context employ a household-level analysis, although some are based on a few in-depth case studies and others on widely administered surveys. Almost all of the studies derive some measures of household fuelwood use and analyze factors which determine the supply and demand for wood and their uses. Many of the studies deal at some length with the availability of fuelwood and especially, the amount of time spent by women and children in procurement. As fuelwood is still in many areas available for gathering at no cash cost, its real cost is usually the value of women's and children's labour spent in its collecting, and this has been discussed in many of the papers.

The study of six different villages in Gwagwalada Area Council of the Federal Capital territory of Nigeria aims to get information on women perception of the scarcity of fuelwood, experiences and their adaptation strategies to situations through a survey that directly deals with women of the study area. Findings of this study reveals that 95.7 percent of the women in various settlements opinion that fuelwood is very important to the communities as a major source of energy due to the fact that all home make use of fuelwood. The study also shows the vegetation cover in the study area has been exploited of its natural plants due to fuelwood harvest and this remain one of the most exploited of the forest resource. And 86 percent of the women in the six villages of the study area agree that there have been scarcity of fuelwood over the years and the issue was said to be instigating changes in food cooking habits as the number of cooking times have to be reduce to once or twice a 
day. The results shows that there are no significant differences in all the responses by respondents in the six villages studied on their opinion on fuelwood scarcity and adaptation strategies at 0.05 and 0.01 alpha levels. The study further shows that recently efficient stoves are being used mostly by those who use charcoal for cooking, in recent time women and children have to walk longer distance to get fuelwood. In adapting to these fuelwood crisis with the aim of maintaining sustainable exploitation of fuelwood as well as reducing the results of fuelwood gathering, women presently make use of straws, charcoal, efficient stoves, different types of pots that gets heated easily, planting of non native plants which may in the long run be used as sources of fuel. ( Ishaya et.al 2009)

Fuelwood, while 'free' financially, incurs opportunity costs in the form of collection labour time (Amacher et al., 1993).

An estimated $84 \%$ of rural women aged 10-59 years are affected by fuel-wood scarcity in India (UN 1995). In rural India inefficient combustion of biofuels in traditional cook stoves with very low thermal efficiency produces smoke which can cause a variety of health problems such as conjunctivitis, acute respiratory infections, upper respiratory irritation, etc. (Batliwala 1995)

A study of 404 households in 31 villages surrounding two forest reserves in Malawi finds that family size, distance, poverty, fuelwood collection restrictions and participation in forest co-management programme etc. are the important determinants of household's choice of fuelwood collection resource. According to the findings of this study, an increase in the size of family by 1 unit reduces the probability of fuelwood collection from the forest reserves by 1.9 percent points and increase the probability of fuelwood collection from plantation forests and customary forests by 1.6 percent points and 0.3 percent points. Study also find that, an extra kilometer from the forest reserve reduces the propensity of fuelwood collection from both forest reserve by 3.7 percent points, while extra pressure on community forests by increasing the probability of fuelwood collection from the source by 7.2 percent point. In addition to this, poverty reduces the probability of fuelwood collection from plantation forests by 14 percentage points and participation in program increases the propensity of fuelwood collection from customary forests by 5.2 percentage points.

Household choose the fuelwood collection resource that maximizes his or her utility. Various results in this study indicate that strong substitution opportunity exists between customary forests and forest reserves, and between customary forests and plantation forests, but limited substitution between plantation forests and forest reserves (Charles, et al. 2011).

Using data from a 1997-98 Malawi Integrated Household Survey (HIS) conducted by the National Statistics Office (NSO), finds that children are significantly involved in resource collection work and their probability of attending school decreases with increase in hours spend on this work. The study further shows that girls spend more hours on resource work and are more likely to be going to school while burdened by this work. Consequently, girls may find difficult to progress well in school. Finally, the study shows that children from the most environmentally degraded districts of central and southern Malawi are less likely to attend school and few of them have progressed to secondary school compared to those from the northern region district.

The NSSO survey regarding nature of demand for fuelwood found that fuelwood to be a normal good in rural area s, while it showed a negative expenditure elasticity of demand (-0.8) for highest income group in urban areas ( Gundimeda and Kohlin, 2003)

Having access to biogas plants, improved cookstoves and micro hydro there was a change in women's workload. The average cooking time per meal after using biogas stoves and Improved Cookstoves, has been reduced from 1.08 hours to 0.75 hours. Similarly, cooking time for morning and afternoon snacks has been reduced from 0.85 hours to 0.59 hours.( Mahat, 2004)

Another study of six states of India with sample size of more than 5000 households in 180 villages related to improved cook stoves, biogas plants, kerosene, LPGs and Electricity in relation to total time saved with the use of these modern fuel in place of fuelwood. This study shows that use of Improved Stoves reduces cooking time by 0.13 hours and reduces fuel collection time by 0.16 hours. And with access to biogas plants women spend less time in cooking and practically no time collecting fuel. With the use of Kerosene for cooking purpose, fuelwood collection time reduced from 0.76 hours per day for households using biomass only to 0.39 hours for those using kerosene. To find out the time saved by women in cooking and fuelwood collection with the use of LPG, a sample size of 518 LPG users and 4528 non-LPG users has been taken. Findings showed that cooking time reduced from 2.74 hours per day for households using biomass only to 2.3 hours for those using LPG. And fuelwood collection time reduced from 0.76 hours for households using biomass only to 0.52 hours for those using LPG. For electricity sample size of 2012 households without electricity and 3036 households with electricity has taken and findings showed that time spent in collecting fuelwood is related both to having electricity and to household income. At all levels of income, the time spent collecting fuel in households with electricity is lower than for those households without electricity. Households without electricity spend 0.9 hours in collecting fuel and 2.93 hours in cooking as against 0.53 hours and 2.58 hours spent by households with electricity for the same tasks. ( Sen et.al,2003). 
Renewable power remains too costly for large scale applications in the countries where poverty alleviation is the primary objective. Stand-alone renewable generation is cost effective alternative to centralized grid supply. The study further point out that decentralized renewable power expansion in Sub-Saharan countries can't be a universal solution to universal access, but it will likely be an important significant expansion in the electricity access. Decentralized renewable are competitive mostly in remote and rural areas while grid connected supply dominates urban areas or denser areas. ( Uwe Deichmann et. al. 2011)

The study of eight developing nations including India, shows electrification, per-capita expenditure and education in most cases significantly increase the probability of using modern fuels. The data collected from Brazil, Ghana, Guatemala, India, Nepal, Nicaragua, South Africa and Vietnam in the study shows clearly demonstrates that solid fuel use decreases with electrification, rising per-capita expenditure and increasing education in most cases. The study further shows that higher education of women in the household translates into higher opportunity costs of fuelwood collection time motivating fuel switching in order to save on the time of these women. (Rasmus Heltberg, 2004)

When there is access to forest stock, people tend to substitute private fuels with forest fuelwood and, even in case of increasing scarcity and more collection time, the extraction does not stop.( Heltberg et al. 2000).

A survey from 404 households in 31 villages surrounding two forest reserves in Malawi and they yielded several important insights. Firstly, a strong correlation between specific attributes of fuelwood sources and household's choice of collection source. Specially, they find that area of fuelwood source, fuelwood species and distance to the fuelwood source are important determinants of households choice of collection resources. Further they find that customary forests and forest reserves are good substitutes while plantation forests and reserve forests are more limited substitutes. Secondly, although fuelwood collection from the forest reserve under Forest Co-Management Programme (FCM) is subjected to regulations and restrictions, they find no significant evidence to suggest that these restrictions deter households from collecting fuelwood from the forest reserves. (Angelson et.al,2011).

A sample size of total 198 women respondents were taken consisting 78 women from the ICS program areas and 120 women from nearby the ICS program area, were interviewed through structured questionnaire .Their response was positive with 73 percent women respondents mentioned that they required less time in cooking after having access to improved cook stove.( Ali, 2002)

The general pattern in developing countries is that with increasing income people generally move up the energy ladder from firewood to charcoal or kerosene and then to liquefied petroleum gas (LPG), natural gas, or electricity for cooking. This upward shift occurs most often in urban areas, because in rural areas, scarce cash income, combined with freely available biomass resources, leads people to continue to rely on biomass for cooking. Indeed, when firewood is scarce in rural areas, residents typically move down the ladder to crop residues and dung (a phenomenon commonly seen in Asia), and occasionally they even turn to grass and roots for cooking energy. Another factor impeding the movement toward more modern fuels, in both rural and urban settings, is declining incomes. In addition, poor distribution systems for modern fuels, especially in smaller cities and towns, have prevented many families from switching to modern fuels. (Alam and others 1975; Barnes and Qian 1992; Leach 1986, 1988; Jones 1988; Reddy and Reddy 1983; Natarajan 1985)

Households that are heavily dependent on forests are an important source of forest degradation and tend to be quite vulnerable to the effects of forest decline. Thus there exists a "vicious circle" in which the rural poor are both agents and victims of resource degradation ( Schreiber et.al, 1994).

Energy policies that emphasis a broader range of renewable and target income generating activities are likely to yield greater benefits to the rural poor than the current policies that rely on the solar Photovoltaic (PVs) option. A renewable energy strategy that relies on a wider range of renewable technologies can ensure that the poor select the technology that best fits their comparative advantage as well as their incomes. The energy options like micro/Pico-hydropower, wind pumps, cleaner fuels such as LPG \& Kerosene etc. could significantly improve the performance of rural-small and micro enterprises and reduce the negative impact of biomass use on women and children's health. ( Kithyoma et.al, 2002)

As income level improves, households may switch over to other cleaner market energy sources such as such as kerosene or coal instead of fuelwood and this reduces the pressure on the forests and saves labour time. (Chen et.al. 2006).

Households respond to economic scarcity, as measured by the opportunity costs of collecting fuelwood, by reducing energy consumption slightly more than by increasing labor input to collection, but found limited evidence for substitution from fuelwood to other energy sources, particularly with declining availability of forest stocks. The market participants were found to be more sensitive to price changes than non-participants. Another result of the study is the limited substitution of fuelwood with other energy sources, particularly with declining availability of forest stocks. All estimated elasticity was found to be low. (Palmer et.al, 2009).

On the other hand, some case studies have found that as household income goes up, the quantity of biofuels used also increases. This necessitates that energy technologies such as improved chulhas and biogas 
need to be promoted more strongly to ensure a sustainable use of the local resources and an improved quality of life for the rural people. (Singh ,1993).

An estimated $84 \%$ of rural women aged 10-59 years are affected by fuel-wood scarcity in India. (UN, 1995)

Another study of Lag valley of Kullu district, Himachal Pradesh, India showed that with the use of LPG for domestic cooking purposes, fuelwood collection has reduced from 7 trips a week to 1 to 4 trips a week, varying between 2 and 6 hours depending on the distance of the forest. Daily cooking time is reduced by 1 to 2 hours for most women in the study area. One of the notable findings of this study was that only in a few cases was the saved time devoted to income generating activities. ( Tandon et.al,2004)

There is a clear correlation between access to modern cooking and social and economic development. According to this paper, both public and private sectors can play important role in promoting clean cooking and providing a brief overview of two public-private partnerships-one in the area of fuels and another focused on the improved cook stoves and fuels. Public-private partnerships try for the optimal allocation of resources, risks and rewards among the partners and aim at efficiently providing services or assets. It is largely accepted that the private sector is the main engine of economic growth. This paper highlights the transition to LPG.

The LPG Rural Energy Challenge is one of the main initiatives that emerged from the world summit on sustainable development (USSD) held in Johannesburg in 2002.This initiative was originally a public-private partnership between the world Liquefied Petroleum Gas Association (WLPGA) and United Nations Development Programme (UNDP). The LPG challenge is designed to create viable and sustainable markets for LPG delivery and consumption by contributing to sustainable energy solutions that can improve people's live in developing countries. The partnership has been successful at establishing and executing a process for multistakeholders dialog in several pilot countries namely China, Ghana, Morocco, South Africa and Turkey. For the people who lack access to sufficient livestock and biomass production and who are unable or unwilling to pay for LPG, another option for them to improve the efficiency with which they burn biomass (or solid fuels). Improved cookstoves (ICS) offer a feasible alternative.

The global alliance for clean cookstoves is a new public-private partnership led by the UN foundation to create a flourished global market for clean and efficient household cooking solutions. This scheme's initial goal call for 100 million homes to adopt clean and efficient cooking stoves and fuels by 2020 .

As the area lacking access to the modern fuels and cookstoves is so vast and has so many interrelationships with other areas of policy, so strong public-private partnerships allow for more effective and directed international effort. (Morgen, et al. 2011)

\section{Objectives}

- To analyze the effects of fuelwood scarcity on the life of rural women.

- To understand the link among poverty, fuelwood scarcity and impacts on women.

- To suggest measures for the problem of fuelwood scarcity.

\section{Fuelwood Scarcity and women}

Women and girls are traditionally responsible for collecting fuelwood for domestic purposes in many parts of developing countries including India. The percentage of women involved in collecting fuel wood and other forest product tasks may vary from region to region. Due to lack of proper market for biomass the price of biomass for these non-market participants is determined by the biomass available and the opportunity cost of collection labor which becomes more pronounced given the fact that members of these communities especially women and children walk many miles to get a head load of fuel wood every day.

\subsection{Increase in women time burden}

As we know that collecting fuel wood is a time consuming and exhausting task. The detrimental effects of fuelwood scarcity and scarcity of alternative sources of fuel are mostly felt by women as a social group, poor rural women in particular.

In a Sudanese study, Agarwal documented a shift from a 15-20 minute walk to 1-2 hours as women are forced to walk longer distances to get fuelwood supplies.

The fuelwood scarcity has resulted in women's loss of time. The gathering of fuelwood and fodder, which used to take about 2 hours, now takes a whole day. Agarwal found that time spent on collecting firewood in Sudan has increased fourfold.

Women time burden for the collection of fuel wood tends to increase in cases where men migrate to urban centers in research of employment. 


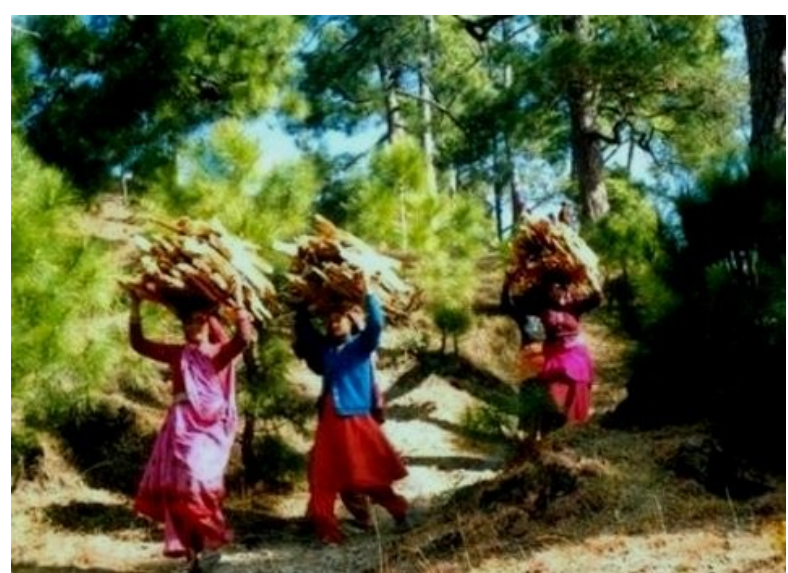

Women engaged in carrying fuelwood at distance from their residence.

\subsection{Effect on Physical health of women}

Women can suffer serious long-term physical damage from strenuous work without sufficient recuperation. This risk, as well as the hazard of falls from tree, bites from venomous snakes, spiders and insects or human assault etc. rises steeply the further from home they have to walk. Because of fuelwood scarcity women in some villages move in a group walking $12 \mathrm{~km}$ or more, spending the whole day searching for firewood. They carry heavy loads of wood which affect the back bone. This is very dangerous, especially to pregnant women. Hospitals have developed a habit of admitting pregnant women so as to keep them away from heavy work.

In addition to these women have concerns with the risk associated stealing fuelwood (e.g. Breaking their legs while running, financial penalties, etc.) from private forests since they did not have access to community forests. Fuelwood scarcity causes direct impact on women's health-rates of maternal death, impact on their participation in important activities like family planning programs, health and nutrition programs.

\subsection{Education}

Fuelwood scarcity places major demands on women and children's time, limiting their opportunities to obtain an education. An increase in the fuelwood collection time may force girls to drop out of schools to asset their mothers in households and other chores, thus hindering their education. In the southern states of Tamil Nadu in India a major reason for keeping girls of age 10-12 is to help the mothers in collecting cow dung (Mencher 1989).

\subsection{Income generating opportunities}

Increased time spent on fuelwood collection and cooking means that women are left with less time for productive, income-generating activities.

Fuelwood scarcity adversely affected women's income generating activities like-sewing, handicrafts etc. Fuelwood is also a key raw material for most of women's major income-generating activities, such as food processing, beer brewing and pottery. But very little is documented on this in the literature. Changes in actual collection time come closer to a welfare impact, but needs to be weighted by the opportunity cost of time.

\subsection{Fuelwood scarcity affects healthy choices}

Fuelwood scarcity also affects women's cooking habits; women do not boil water enough, cook food items with low nutritional value that require less cooking time. This, in turn, affects family health. Women, especially become victims of a different health hazard due to firewood scarcity.

In areas where fuelwood is scarce, people may also be obliged to make unhealthy choices such as eating half cooked meals, cook the food at one time for the whole day, low nutritional value food items are cooked that requires less cooking time etc. which affected the health of all family members but especially the pregnant women and children.

Shortage of fuelwood tends to limit basic health practices, for example, nor sterilizing children's feeding bottles by boiling because of lack of fuel. Significantly, the burden of the fuelwood and domestic energy crisis in general, is often borne by women who culturally have it as their responsibility to meet the energy needs of their households through fuel collection, preparation and use. 


\subsection{Greater Probability of militancy victim}

In the hilly areas of the state like Jammu and Kashmir that is militancy affected state, the women have to face the brunt of the armed militants while they are gone to the nearby forests to collect fuel wood, this has adversely affected their mobility, leading to a peculiar situation, for them fuel wood is not available in the village and these communities, especially women are not in a position to go to the forests.

\subsection{Change in cooking habits}

Fuelwood scarcity leads to fewer meals cooked the substitution of quickly cooked foods for slow cooking foods and the substitution of raw and cold dishes. In a Mexican study, most women said they were cooking fewer beans because they did not have enough firewood with which to cook them.

Problems of fuel scarcity may affect household food consumption patterns as in changes in cooking habits, and reduction in the number of cooked meals and types of food cooked. This may mean cooking and eating less nutritious foods (which need less energy to cook).

\subsection{Other domestic functions}

The more time women spend on biomass collection, preparation, and use, the less time they have for other domestic functions .For example, less time available for infant and child care, especially breastfeeding. Infants are deprived of vital breast milk if the mother spends too much time away from home. Less time for rest and other household activities such as giving the necessary love and attention to the children.

The non-availability of fuel wood within the villages is an indicator of the forests in these areas have been over exploited, given the fact that, in the past, this was not the situation and people would have enough forests within the villages itself to fulfill their requirements.

Projects/programs have not focused directly on increasing income and employment for women. The programmes for afforestation in India must be given a new direction. The scarcity of fuelwood is not always study in relation to women and children who are highly involved in the harvesting of fuelwood. In order to put the fuelwood scarcity to its minimum level, there is a need for understanding women perception of fuelwood scarcity, the strategies women adopted in tackling fuelwood scarcity.

\section{A Chart showing some common impacts of fuelwood scarcity on women.}

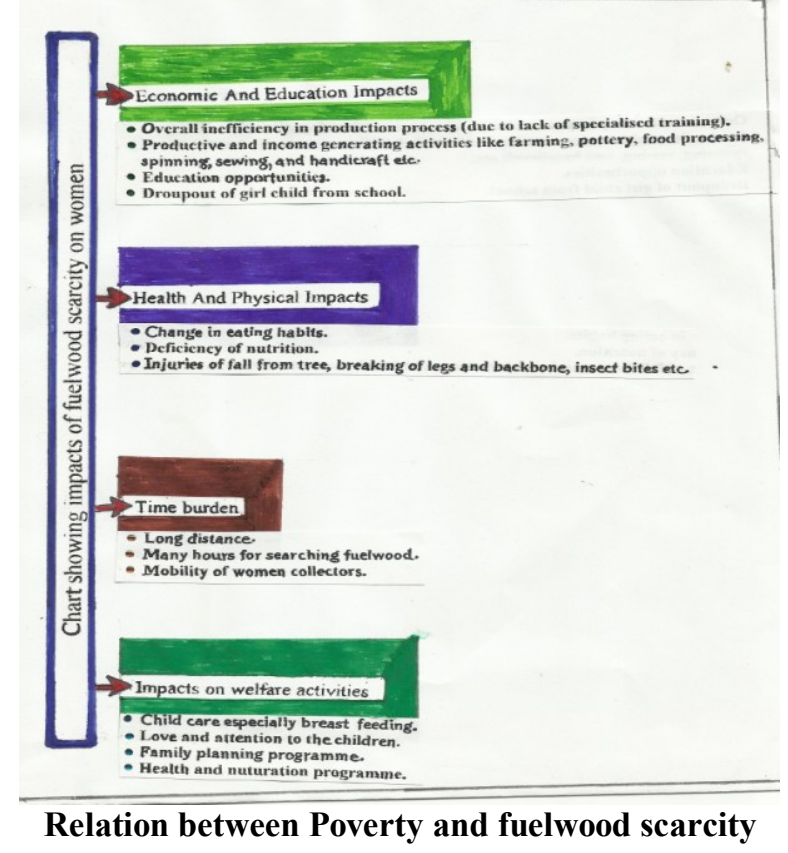

The international community has long been aware of the close correlation between income levels and access to modern energy: not surprising, countries with a large proportion of the population living on an income of less than US Dollar 2 per day tend to have low electrification rates and a high proportion of the population relying on traditional biomass.

The 2010 edition of the World Energy Outlook (WEO) assesses two indicators of energy poverty at the household level: the lack of access to electricity and the reliance on the traditional use of biomass for cooking. The UN Millennium Development Goal of eradicating extreme poverty by 2015 will not be achieved unless substantial progress is made on improving energy access. 
Household's economic wealth is a key factor in explaining energy use behavior and the substitution of private fuels to commercial energy sources.

When firewood becomes scarce and more difficult to access, an additional indirect financial costs related to the increase in firewood price or a substitution towards more expensive sources of energy, all contribute to a decreasing well-being of local people.

Various interrelated questions can be raised. First, does biomass consumption, reduce when income grows? If the relationship is found to be negative, the pressure on forests can be expected to decrease as a country develops. The empirical literature on the poverty-environment hypothesis (PEH) addresses this question and states that poor households rely more on environmental resources than the non-poor. Where evidence of the $\mathrm{PEH}$ can be found, there are at least two main policy implications. First, poverty alleviation is a precondition for environment sustainability. Second, environmental protection policies based on a drastic limitation of access to common resources increase rural inequality and deepen poverty because poorer households suffer more intensively from the deprivation of the resource.

The main economic dimensions highlighted in the literature on the relationship between poverty and forest degradation through firewood collection include income, opportunity costs, preferences, market imperfections, institutional weaknesses and credit constraints ([Arnold et al.,2003], [Arnold et al.,2006], [Cooke et al.,2008] and[ Wunder,2001].

Poverty and fuelwood scarcity appear to go hand in hand in developing countries. Loss of forest cover in these countries are attributed to agriculture expansion, biomass use for fuelwood, charcoal production, brick burning and other factors. With population growth and increase in poverty and unemployment, this increasing demand for fuelwood for cooking is considered a serious threat to forests.

Households that are heavily dependent on fuelwood are an important source of forest degradation and tend to be quite vulnerable to the effects of forest decline. Thus, there exists a 'vicious circle' in which the rural poor are both agents and victims of resource degradation.

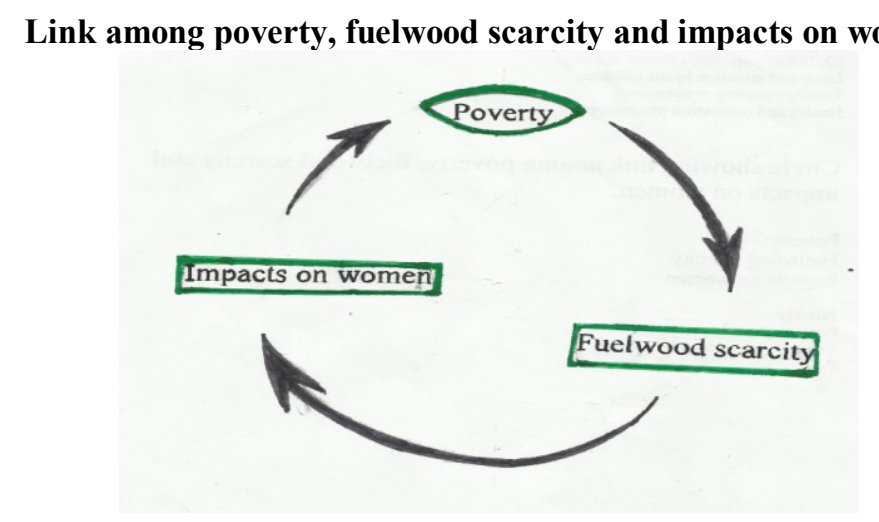

This circle shows an important link among poverty, fuelwood scarcity, and its impacts on women.

When people are poor, they have less purchasing power and are not in a condition to purchase modern fuels like LPGs, kerosene etc. from the market. These poor people cannot adopt other alternatives or substitutes like modern efficient stoves, solar cookers etc. to fuelwood especially who belong to rural areas or who reside near by the forests. These people mostly used fuelwood for cooking food, lightning and for heating rooms and space particularly during winters resulted into depleting of forests day by day and led to the problem of fwelwood scarcity.

With the scarcity of fuelwood, women who are traditionally responsible to search, collect, load and carry fuelwood from the forests in most parts of the underdeveloped and developing nations have to spend more hours for searching and collecting fuelwood. Now, with increasing scarcity of fuelwood, they have to cover large distance which results into the wastage of precious time hindering other important activities of women limiting their opportunities to earnings and obtain education. This process again put them into the grip of poverty, poverty again responsible for fuelwood scarcity which again led to deterioration of women economically, socially, and physically. This process of circle again and again repeats in itself. Solution to

\section{fuelwood scarcity}

The effects of fuelwood scarcity on environment and inhaling biomass smoke during cooking are receiving increased attention from researchers, but the impacts of fuelwood shortages on women's income generating activities, education, health, cooking and nutrition are scarcely noticed by the researches,policy makers and government bodies. The main aim of this paper is consistent and urgent: women need relief from their burden of work. 
Fuel Efficient Stoves: In some places cooking is a particularly time-consuming task, so an improved stove which cooks faster may be a source of delight. Elsewhere, fuel-management strategies by women save more fuel than carefully planned stove programmes. Stove technologists can offer choices, but decisions about household energy technologies should be in the hands of women, the real experts on cooking. The improved biomass stoves/Fuel efficient stoves save so much fuelwood. The stove accommodates 2 cooking pans at the same time. It is raised and smokeless. It uses a maximum of 4 pieces of wood and retains heat for at least 6 hours. Wood fuel collected over the weekend can last for the whole week so children do not miss school to search for firewood. Mothers are capable of preparing 4 meals a day i.e. breakfast, tea break, lunch and supper, while those with a 3 stone fire get only one meal a day. This has reduced cases of rape and attempted rape by unscrupulous gangsters who way-lay these girls on the way to collect firewood. Time burden of women may be reduced by providing modern stoves (Fuel Efficient Stoves) at highly subsidized rates to Below Poverty Line (BPL) families and at moderate rates to middle income-families.
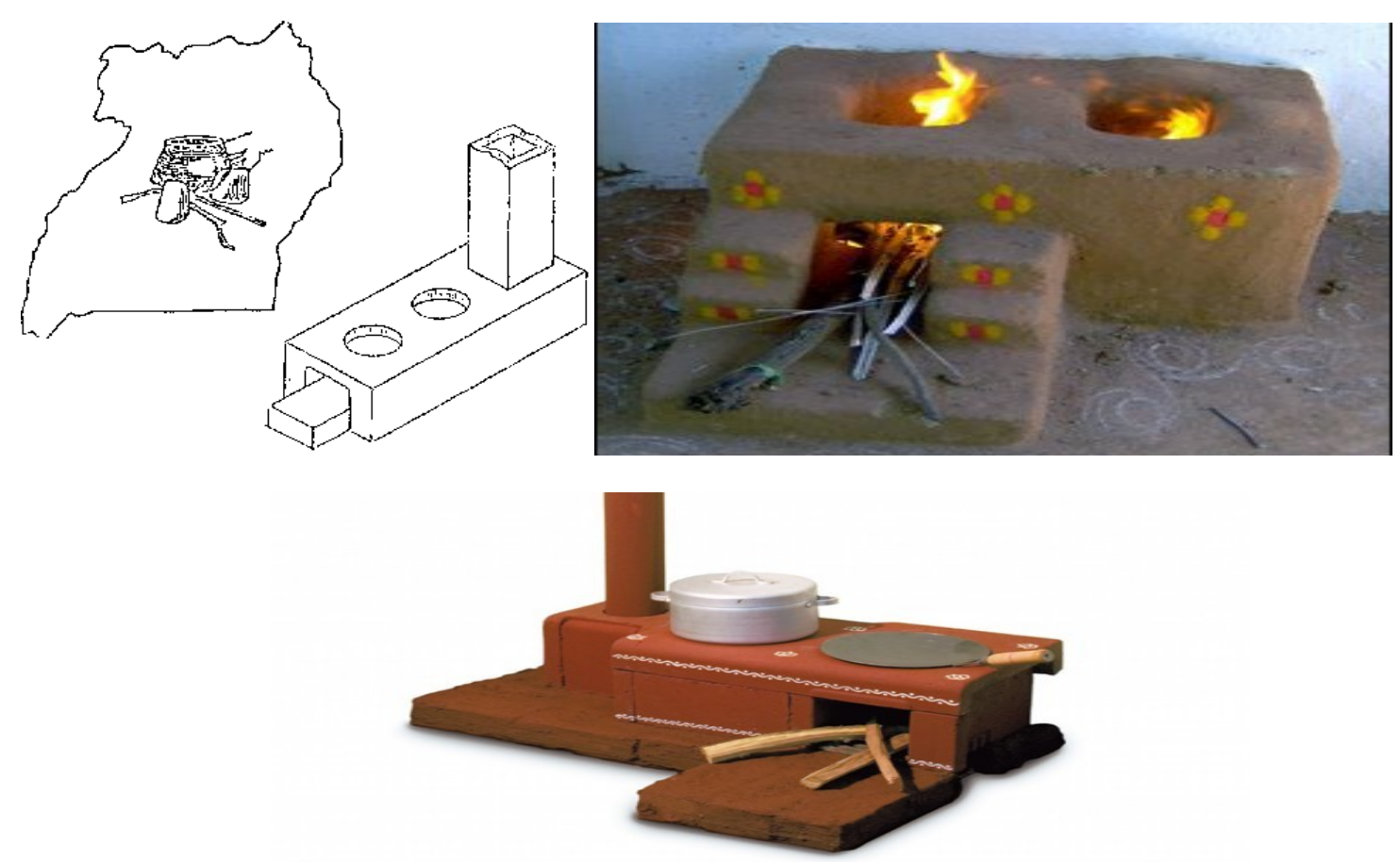

Fuel Efficient Stoves/Chullah that requires less quantity of fuelwood for cooking and these chullah are also smokeless.

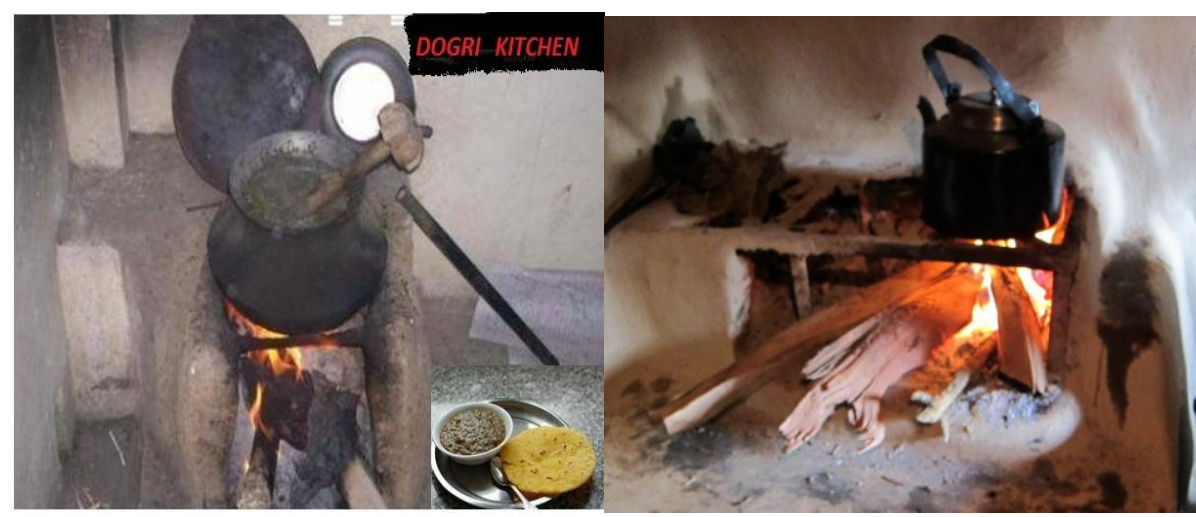

Traditional-chullah (chullah with very low efficiency,full of smoke and require large quantity of fuelwood for cooking) in village Parand of district Udhampur (Jammu and Kashmir-India).

Emphasize the role of women: Although it might seem obvious that projects related to fuelwood scarcity and environment should be planned and carried out with and for women, but they are hardly ever considered. Many projects which are carried out in the environmental field do not offer any advantages for women, and even have clearly noticeable disadvantages. 
In carrying out the project a large number of the administrative and technical personnel and advisers of the project should be women. The activities within the project must correspond to women's capabilities and qualifications in the amount of work, the time planning, the equipment and techniques used, and in the organization of the work. While planning the project the women's needs have to be studied and considered with a participatory approach. The women have to learn about more ways in which they can improve their lives. Training should be given to them regarding use of fuelwood efficiently through variety of modern techniques and other cheap alternatives.

Fuel switching: Fuelwood substitutes like cow dung, electricity, kerosene, in some cases LPGs etc. can save the time of women for income generating and other welfare activities. Improved access to electricity and modern fuels reduces the physical burden associated with carrying wood and frees up valuable time, especially for women, widening their employment opportunities. Where modern technologies are available for cooking i.e LPG, biogas, improved stoves etc. men also share the cooking responsibilities such as preparing light snacks, carrying cylinders for family but where these modern technologies are absent women and children are mostly responsible. Also poor distribution systems for modern fuels, especially in smaller cities and towns, have prevented many families from switching to modern fuels.

Therefore, government should make arrangements to provide these substitutions like kerosene, electricity and LPGs etc. especially to the families of fuelwood deficit areas with special subsidize criteria for BPL family substituting fuelwood with alternative fuels.

Social forestry: Government should undertake activities like social forestry which includes trees of fodder and fruits to deal with problem of fuelwood scarcity and to increase forest cover .Often government undertake activities of social forestry on small scale which is not enough to deal with problem of fuelwood scarcity. The trees of fruits like apple, mango, apricot in hilly areas and other fruit trees in plains can deal with twin problem of forest degradation and fuelwood scarcity.

Awareness among rural masses: Awareness through mass media , educational institutions and other various means can help in increasing awareness among people to plant more trees in villages can go a long way in dealing with problem of fuelwood scarcity.

Income and employment opportunities: New Programmes/Projects should be designed to focus on providing direct income and employment opportunities for rural women.

\section{Conclusion}

The widening of the gap between demand for and supply of fuelwood due to multiple reasons led to the problem of fuelwood scarcity. An increase in the fuelwood collection time may force girls to drop out of schools to asset their mothers in households and other chores, thus hindering their education. It also affects their cooking habits which affect the health of all family members, but especially the pregnant women and children. Poverty and unemployment are the basic cause of why people mostly used fuelwood in developing countries especially in India. When people are poor, they have less purchasing power and are not in a condition to purchase modern fuels and depend primarily on fuelwood for cooking food; lightning and heating rooms resulted into depleting of forests day by day and led to the problem of fuelwood scarcity.Time burden of women may be reduced by providing modern fuels and stoves at highly subsidized rates to Below Poverty Line (BPL) families and at moderate rates to middle income families. Where modern technologies are available for cooking i.e. LPG, biogas, improved stoves, etc. men also share the cooking responsibilities such as preparing light snacks, carrying cylinders for families and thus can save time of women for income generating activities, participating welfare activities etc.

Projects/programs should focus directly on increasing income and employment for women. There is a need to study scarcity of fuelwood in relation to women and children who are highly involved in the harvesting of fuelwood in most part of the India. The programs for afforestation in India must be given a new direction. In order to put the fuelwood scarcity to its minimum level, there is a need for understanding women perception of fuelwood scarcity, the strategies women adopted in tackling fuelwood scarcity.

\section{References}

[1]. Amacher, G.S., Hyde, W.F., \& Joshee, B.R. (1996). Household fuelwood demand and supply in Nepal's Tarai and Mid-Hills: choice between cash outlays and labor opportunity, World Development report, 24, 1725-1736.

[2]. Arnold, M., K“ohlin, G., Persson, R., \& Shepherd, G. (2003). Fuelwood revisited: what has changed in the last decade? Center for International Forestry Research (CIFOR), Bogor, Indonesia, Occasional Paper No. 39, 35.

[3]. Barnes, D., \& Sen, M. (2003). The impact of energy on women's lives in rural India, UNDP/ESMAP.

[4]. Batliwala, S. (1995). Bearing the brunt of labor, The Hindu Survey of the Environment Kasturi \& Sons Ltd. Madras.

[5]. Charles, P., \& MacGregor, J. (2009). Fuelwood scarcity, energy substitution, and rural livelihoods in Namibia, Cambridge University Press, 1-23.

[6]. Chen, L., Heerink, N., \& Berg, M. van den. (2006). Energy consumption in rural China: a household model for three villages in Jiangxi Province, Ecological Economics, 58,407-420. 
[7]. Chopra, K., Kadekodi, G.K., \& Murty, M.N. (1990). Participatory Development : People and common property Resources, New Delhi: Sage.

[8]. Conroy, C. (1991). The contribution of farm forestry to rural livlihoods: a case study from eastern Gujarat, Social forestry network paper.

[9]. Dutta, S.(2005). Energy as a key variable in eradicating extreme poverty and hunger: A gender and energy perspective on empirical evidence on MDG\#1, Discussion Paper,39-42.

[10]. Gundimeda, H., \& Kohlin,G. (2003).Fuel demand elasticities for energy and environment studies:Indian Sample Survey evidence, Environmental Economics Unit, Depaetment of Economics, Goteborg University, Sweden.

[11]. Heltberg, R., Channing T.C., \& Sekhar N.U. (2000).Fuelwood consumption and forest degradation: a household model for domestic energy substitution in rural India, Land Economics, 76, 213-232.

[12]. Ishaya, S., Grace, J. M., \& Mohammed, A.M. (2009). Fuelwood scarcity: Women's perception, experience and adaptation strategies in Gwagwalada Area Council, Nigeria,3(1),79-84.

[13]. Jumble, C.B.L., \& Angelsen, A. (2011). Modeling choice of fuelwood source among rural households in Malawi : A multinominal probit analysis, Journal of Energy Economics, 33,732-738.

[14]. Leach, G. (1992). The Energy Transition, Energy Policy, 20,116-123.

[15]. Ramus, H. (2004). Fuelswitching: evidence from eight developing countries, Energy Economics, 26,869-887.

[16]. Reddy, A. K., \& Reddy, B.S. (1983). Energy in a Stratified Society: Case Study of Firewood in Bangalore, Economic and Political Weekly, 17(41), 8 .

[17]. Singh, D. V. (1993). Energy use pattern of rural households in Himalayas: case of Himachal Pradesh, Energy Environment monitor, 9(1), 11-14.

[18]. Stephen, K., \& Waeni, K. (2002). Renewable energy strategies for rural Africa : is a PV- led renewable energy strategy the right approach for providing modern energy to the rural poor of Sub-Saharan Africa?, Journal of Energy Policy, 30, 1071-1086.

[19]. UN. (1995). World's Women 1995: Trends \& Statistics, New York: United Nations .

[20]. Uwe, D., Craig M., Siobhan, M., \& David, W. (2011). The economics of renewable energy expansion in rural Sub-Saharan Africa, Journal of Energy Economics, 39,215-227.

\section{Tables}

The percentage wise energy composition of different fuels used in the rural households of India is shown in Table(A).

Table( A) Energy mix in households of rural India

Source: NSSO 2001

\begin{tabular}{|l|c|}
\hline Types of fuel & Energy Consumption( in percentage ) \\
\hline Fuelwood & 63 \\
\hline Dung cake & 11 \\
\hline Coal & 2 \\
\hline Kerosene & 3 \\
\hline LPG & 4 \\
\hline Crop residue & 14 \\
\hline Others & 3 \\
\hline
\end{tabular}

Pie chart of Table (A)

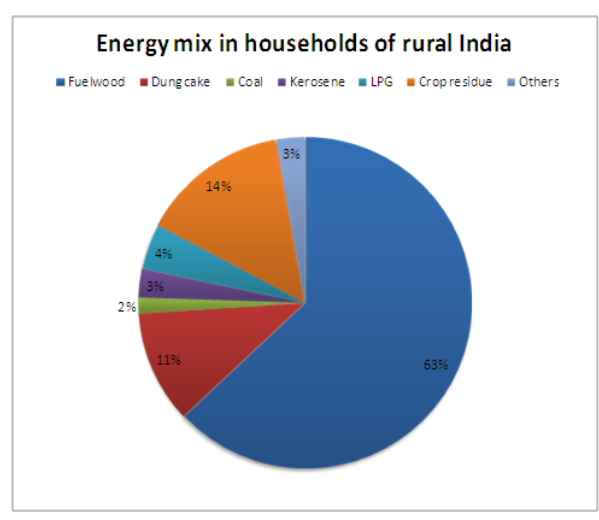

Table(B): shows the number and share of the population relying on the traditional use of biomass as their cooking fuel by region, 2009-10 (in million).

\begin{tabular}{|l|c|c|c|c|}
\hline Developing Regions & Rural & Urban & Total & Share of total population in percentage \\
\hline Africa & 481 & 176 & 657 & $67 \%$ \\
Sub-Saharan Africa & 477 & 176 & 653 & $80 \%$ \\
Developing Asia & 1694 & 243 & 1937 & $55 \%$ \\
China & 377 & 47 & 423 & $32 \%$ \\
India & 765 & 90 & 855 & $75 \%$ \\
Other Asia & 553 & 106 & 659 & $63 \%$ \\
Latin America & 60 & 24 & 85 & $18 \%$ \\
\hline Developing Countries & 2235 & 444 & 2679 & $54 \%$ \\
\hline
\end{tabular}

Source: OECD/IEA Report 2010 
Note: Includes developing Asia countries except China and India.

Table (C) shows the projection of the International Energy Agency related to the number of people dependent on fuelwood from different Countries for the year 2004, 2015 and 2030.

Table(C): People (in millions) relying on fuelwood.

\begin{tabular}{|l|l|l|l|}
\hline Countries & 2004 & 2015 & 2030 \\
\hline Sub-Saharan Africa & 575 & 627 & 720 \\
\hline North Africa & 4 & 5 & 5 \\
\hline India & 740 & 777 & 782 \\
\hline China & 480 & 453 & 394 \\
\hline Indonesia & 156 & 171 & 180 \\
\hline Rest of Asia & 489 & 521 & 561 \\
\hline Brazil & 23 & 26 & 27 \\
\hline Rest of Latin America & 60 & 60 & 58 \\
\hline Total & 2,528 & 2,640 & 2,727 \\
\hline
\end{tabular}

Source: International Energy Agency (IEA) 2006

\section{Empirical evidences of time saving by women with modern fuels}

Table(D) :Time saved by women in cooking and fuel wood collection with modern fuels and stoves.

\begin{tabular}{|c|c|c|c|c|}
\hline Study & Location & Sample Size & $\begin{array}{l}\text { Type of Fuel/ } \\
\text { Stove }\end{array}$ & Total time saved \\
\hline Ali 2002 & $\begin{array}{l}\text { Kalampur and } \\
\text { Kaliakor Thana } \\
\text { where } \\
\text { government } \\
\text { provided } \\
\text { improved } \\
\text { cookstoves. }\end{array}$ & $\begin{array}{l}198 \text { women, } \\
\text { were } \\
\text { interviewed } \\
\text { through a } \\
\text { structured } \\
\text { questionnaire. }\end{array}$ & $\begin{array}{l}\text { Improved } \\
\text { cookstove }\end{array}$ & $\begin{array}{l}73 \% \text { respondents mentioned "less time required" } \\
\text { in cooking. }\end{array}$ \\
\hline $\begin{array}{l}\text { Barnes and Sen } \\
2003\end{array}$ & Six states of India & $\begin{array}{l}5,000 \text { households } \\
\text { in } \\
180 \text { villages }\end{array}$ & $\begin{array}{l}\text { Improved } \\
\text { cookstove }\end{array}$ & $\begin{array}{l}\text { Use of ICs reduces cooking time by } 0.13 \text { hours } \\
\text { and fuel collection time } \\
\text { by } 0.16 \text { hours. }\end{array}$ \\
\hline $\begin{array}{l}\text { Barnes and Sen } \\
2003\end{array}$ & Same as above & Same as above & Kerosene & $\begin{array}{l}\text { Fuelwood collection time reduced from } 0.76 \\
\text { hours/day for households } \\
\text { using biomass only to } 0.39 \text { hours for those using } \\
\text { kerosene. }\end{array}$ \\
\hline $\begin{array}{l}\text { Barens and Sen } \\
2003\end{array}$ & Same as above & $\begin{array}{l}518 \text { users } \\
\text { and } 4528 \text { non } \\
\text { users }\end{array}$ & LPG & $\begin{array}{l}\text { Cooking time reduced from } 2.74 \text { hours/day for } \\
\text { households using biomass only to } 2.3 \text { hours for } \\
\text { those using LPG. } \\
\text { Fuelwood collection time reduced from } 0.76 \\
\text { hours for households using biomass only to } 0.52 \\
\text { hours for those using LPG. }\end{array}$ \\
\hline $\begin{array}{l}\text { Barens and Sen } \\
2003\end{array}$ & Same as above & $\begin{array}{l}2012 \text { households } \\
\text { without } \\
\text { electricity and } \\
3036 \text { households } \\
\text { with } \\
\text { electricity) }\end{array}$ & Electricity & $\begin{array}{l}\text { At all levels of income, the time spent in } \\
\text { collecting Fuelwood in households with } \\
\text { electricity is lower than for those households } \\
\text { without electricity. Households without } \\
\text { electricity spend } 0.90 \text { hours in collecting fuel and } \\
2.93 \text { hours in cooking per day as against } 0.53 \\
\text { hours and } 2.58 \text { hours spent by households with } \\
\text { electricity for the same tasks. }\end{array}$ \\
\hline $\begin{array}{l}\text { Chakrabarti } \\
2002\end{array}$ & $\begin{array}{l}\text { Sagardweep } \\
\text { island in the Bay } \\
\text { of Bengal in } \\
\text { India. }\end{array}$ & $\begin{array}{l}150 \text { households } \\
\text { using SPV power } \\
\text { for lightning (out } \\
\text { of total 475) }\end{array}$ & $\begin{array}{l}\text { SPV power plant } \\
\text { for lightning }\end{array}$ & $\begin{array}{l}38 \text { per cent respondents reported that, on an } \\
\text { average, the use of power has helped to save } \\
\text { cooking time at night by } 1.5 \text { hours. }\end{array}$ \\
\hline $\begin{array}{l}\text { Chander and } \\
\text { Tandon } 2004\end{array}$ & $\begin{array}{l}\text { Lag valley of } \\
\text { Kullu } \\
\text { district, Himachal } \\
\text { Pradesh, India }\end{array}$ & Not mentioned & LPG & $\begin{array}{l}\text { Fuelwood collection has reduced from } 7 \text { trips a } \\
\text { week to } 1 \text { to } 4 \text { trips,varying between } 2 \text { and } 6 \\
\text { hours (depending on the distance of the } \\
\text { forest). In } 9 \text { cases, the collection frequency is } \\
\text { down to } 1 \text { to } 4 \text { trip per month. } \\
\text { Daily cooking time is down by } 1 \text { to } 2 \text { hours for } \\
\text { most women. However, only in a few cases was } \\
\text { the saved time devoted to income generating } \\
\text { activities. }\end{array}$ \\
\hline Conroy 1991 & $\begin{array}{l}\text { Panchmahal } \\
\text { district } \\
\text { of Gujarat, India }\end{array}$ & Not mentioned & Social forestry & $\begin{array}{l}\text { The social forestry project led to self sufficiency } \\
\text { in fuelwood. An earlier study in the same region } \\
\text { found that people (primarily women and } \\
\text { children) used to have to spend } 6-8 \text { hours every } \\
\text { two or three days to collect } 20 \mathrm{~kg} \text { of fuelwood: } \\
\text { mainly from forest lands as much as } 10 \mathrm{~km} \text { away. }\end{array}$ \\
\hline
\end{tabular}




\begin{tabular}{|c|c|c|c|c|}
\hline Chuntao 2002 & $\begin{array}{l}\text { Baima Snow Mt. } \\
\text { Nature Reserve, } \\
\text { Yunnan province, } \\
\text { China }\end{array}$ & Not mentioned & Biogas plants & $\begin{array}{l}\text { By using biogas plants, the women users reported } \\
\text { that they now use half as much as wood before, } \\
\text { and save half the time spent earlier on fuelwood } \\
\text { collection. }\end{array}$ \\
\hline $\begin{array}{l}\text { Eastconsult } \\
2004\end{array}$ & $\begin{array}{l}10 \text { districts of Hill } \\
\text { and Terai of } \\
\text { Nepal }\end{array}$ & $\begin{array}{l}\text { A total of } 200 \\
\text { households ( } 100 \\
\text { with Biogas and } \\
100 \\
\text { without Biogas) } \\
\text { were surveyed. }\end{array}$ & Biogas plants & $\begin{array}{l}\text { Time spent in collecting fuel wood source after } \\
\text { biogas installation is less by } 63.1 \mathrm{~min} / \text { day in } \\
\text { Terai region and } 33.05 \mathrm{~min} / \text { day in hills for } \\
\mathrm{men} \text {. For women, the respective figures are } 111 \\
\mathrm{~min} / \text { day in Terai and } 58.97 \mathrm{~min} / \text { day in the hills. }\end{array}$ \\
\hline ESMAP 2002a & $\begin{array}{l}\text { Andhra Pradesh, } \\
\text { India }\end{array}$ & $\begin{array}{l}134 \text { LPG users, } \\
18 \\
\text { gas agencies and } \\
\text { other villages } \\
\text { level } \\
\text { groups in } 6 \\
\text { districts }\end{array}$ & $\begin{array}{l}\text { LPG under } \\
\text { Deepam } \\
\text { scheme (a one } \\
\text { time } \\
\text { subsidy of Rs } \\
1000 \text { to acquire } \\
\text { LPG connection } \\
\text { for poor } \\
\text { households }\end{array}$ & $\begin{array}{l}97 \% \text { of the respondents stated that using LPG } \\
\text { saved time for cooking }\end{array}$ \\
\hline Mahat 2004 & $\begin{array}{l}\text { Kavre district, } \\
\text { Nepal }\end{array}$ & $\begin{array}{l}\text { Household } \\
\text { surveys } \\
\text { were conducted } \\
\text { in } \\
\text { both project ( } 273 \\
\text { households) and } \\
\text { nonproject } \\
\text { areas (205 } \\
\text { households) and } \\
\text { were } \\
\text { integrated with } \\
\text { participatory } \\
\text { research } \\
\text { methods, in areas } \\
\text { where Rural } \\
\text { Energy } \\
\text { Development } \\
\text { Program (REDP) } \\
\text { was } \\
\text { implemented. } \\
\end{array}$ & $\begin{array}{l}\text { Biogas plants, } \\
\text { improved } \\
\text { cookstoves and } \\
\text { micro } \\
\text { hydro }\end{array}$ & $\begin{array}{l}\text { There was a change in women's workloads after } \\
\text { having access to biogas plants and micro-hydro } \\
\text { mills. The average cooking time per meal after } \\
\text { using biogas stoves and ICS, has been reduced } \\
\text { from } 1.08 \text { hours to } .75 \text { hours. Similarly, cooking } \\
\text { time for morning and afternoon snacks has been } \\
\text { reduced from } .85 \text { hours to } \\
.59 \text { hours. }\end{array}$ \\
\hline Oza 1993 & Gujarat, India & Not mentioned & Biogas plants & $\begin{array}{l}\text { Time spent in kitchen work has come down by } 1 \text { - } \\
2 \mathrm{hr} \text { per day by use of } \\
\text { biogas plants. }\end{array}$ \\
\hline
\end{tabular}

Source: DFID/ENERGIA project on gender as a key variable in Energy Interventions, 2005, 39-42. 